\title{
Utilitas
}

http://journals.cambridge.org/UTI

Additional services for Utilitas:

Email alerts: Click here

Subscriptions: Click here

Commercial reprints: Click here

Terms of use : $\underline{\text { Click here }}$

\section{Why Women Hug their Chains: Wollstonecraft and Adaptive Preferences}

SANDRINE BERGES

Utilitas / Volume 23 / Issue 01 / March 2011, pp 72 - 87

DOI: 10.1017/S0953820810000452, Published online: 15 February 2011

Link to this article: http://journals.cambridge.org/abstract S0953820810000452

How to cite this article:

SANDRINE BERGES (2011). Why Women Hug their Chains: Wollstonecraft and Adaptive Preferences. Utilitas, 23, pp 72-87 doi:10.1017/S0953820810000452

Request Permissions : $\underline{\text { Click here }}$ 


\title{
Why Women Hug their Chains: Wollstonecraft and Adaptive Preferences
}

\author{
SANDRINE BERGES
}

Bilkent University

In a recent article,$^{1}$ Amartya Sen writes that one important influence on his theory of adaptive preferences is Wollstonecraft's account of how some women, though clearly oppressed, are apparently satisfied with their lot. Wollstonecraft's arguments have received little attention so far from contemporary political philosophers, and one might be tempted to dismiss Sen's acknowledgment as a form of gallantry. ${ }^{2}$ That would be wrong. Wollstonecraft does have a lot of interest to say on the topic of why her contemporaries appeared to choose what struck her as oppression, and her views can still help us reflect on contemporary problems such as the ones identified and discussed by Amartya Sen. In this article I will argue that a close look at Wollstonecraft's arguments may lead us to rethink some aspects of Sen's discussion of the phenomenon of adaptive preferences.

\section{SEN'S CONCEPT OF ADAPTIVE PREFERENCES}

In Inequality Re-examined, Sen describes the phenomenon of adaptive preferences as follows:

A thoroughly deprived person, leading a very reduced life, might not appear to be badly off in terms of the mental metric of desire and its fulfillment, if the hardship is accepted with non-grumbling resignation. In situations of longstanding deprivation, the victims do not go on grieving and lamenting all the time, and very often make great effort to take pleasure in small mercies and to cut down personal desires to modest - 'realistic' - proportions. ${ }^{3}$

Sen's theory is based in great part on his own observations of how the destitute and the oppressed tend to describe their own well-being. If, for instance, the inhabitants of a comparatively well-off region of India, Kerala, complain of ill health more than the inhabitants or a poorer region, Bihar, there is likely more to the explanation than that the poor are more resistant to illness than the rich. ${ }^{4}$ Sen's explanation is

1 Amartya Sen, 'Reason, Freedom, and Well-Being', Utilitas 18 (2006), pp. 80-6.

${ }^{2}$ For recent philosophical papers on Wollstonecraft see Lena Halldenius, 'The Primacy of Right: On the Triad of Liberty, Equality and Virtue in Wollstonecraft's Political Thought', British Journal for the History of Philosophy 15 (2007), pp. 75-99; Elizabeth Wingrove, 'Getting Intimate with Wollstonecraft: In the Republic of Letters', Political Theory 33 (2005), pp. 344-69; and Laura Brace, "Not Empire but Equality": Mary Wollstonecraft, the Marriage State and the Sexual Contract', Journal of Political Philosophy 8 (2000), pp. 33-45.

3 Amartya Sen, Inequality Re-examined (Cambridge, Mass., 1992), p. 55.

4 See Sen, 'Reason', p. 88. 
that where standards of healthcare are known to be low, people tend to complain less. Faced with necessary deprivation, people need to forget the gap in their life, they need, for the sake of survival, to became convinced that it was never there. This is how, in another of Sen's examples, women in rural India came to believe that their nutritional needs were close to non-existent, and in any case, inferior to those of their husbands and children.

Sen's identification of this phenomenon led him to reject measurements of well-being based on satisfaction. Because preferences are malleable, being satisfied with one's lot is not a reliable way to measure well-being (with a view to distributing resources). People learn to live with what they can get, and do not waste energy wishing they could get what is unavailable to them. This phenomenon has also been described as sour grapes, after Aesop's fable in which a fox decides that he does not desire the grapes he cannot reach, and tells himself, knowing that it is false, that they were sour anyway. ${ }^{5}$

This self-deception can only end once the deficit is filled, once people are confident that what they were once missing is going to be reliably available from now on. So when a village has access to clean water and its inhabitants have been given basic lessons in hygiene and illness preventions, the women can say proudly 'we are cleaner now'. ${ }^{6}$ Before, they would not have let themselves consider cleanliness to be desirable in any way. Nussbaum writes of one such woman that '[S]he knew that this was how things were and would be... She didn't even waste mental energy getting upset, since these things couldn't be changed. ${ }^{7}$

Sen's view is taken up by Martha Nussbaum who argues that in order to ensure that we have an accurate account of well-being we must develop a list of capabilities which all human beings must have in order to live properly human lives. This list, although it allows for cultural variation, must be universal in order to avoid being undercut by adapted preferences. Nussbaum's central capabilities range from life, health and bodily integrity to control over one's environment, both political and material. ${ }^{8}$ For each item in the list the emphasis is on the capability to function, rather than the functioning itself. So for instance, Nussbaum lists affiliation as a central capability. This means that in order to live a good life, one must have the capability to live with

\footnotetext{
5 Jon Elster, Sour Grapes (Cambridge, 1987) emphasizes that the phenomenon of sour grapes is causal rather than intentional. It is not the case in the examples discussed by Sen and Nussbaum that people choose to deal with disappointment by forcing themselves to forget about it, it is an unconscious process.

${ }^{6}$ Martha Nussbaum, Women and Human Development (Cambridge, 2000), p. 114.

7 Nussbaum, Women and Human Development, p. 113.

${ }^{8}$ For a full and detailed list of the capabilities see Nussbaum, Women and Human Development, pp. 78-80.
} 
others, as part of a community, while not being discriminated against because of race, gender, or anything else. But this does not entail that in order to live a good life one has to live with others. A recluse by choice could very well be happy - what matters is that it is a choice, and not something imposed by the lack of capabilities.

I will discuss Wollstonecraft's position in some detail and from this study it will emerge that only a small percentage of the phenomena that Sen and Nussbaum describe as adaptive preferences are in fact at all like sour grapes. Certainly for Wollstonecraft, I will argue, it makes more sense to talk of stunted growth of preferences ${ }^{9}$ than adapted ones. Women's preferences were 'grown' in a corrupt system which provided them with a distorted frame of references in which to form their values. This kind of problematic preference raises issues that cannot be addressed without going further than Sen, for instance, is willing to go. In particular, they cannot be addressed satisfactorily in a way that wholly avoids paternalism. We need to take a stand and say that some ways of being and thinking are objectively better than others. For this reason, it will be useful to begin by taking a look at the paternalism charges against adaptive preference theory.

\section{THE PATERNALISM CHARGE, AND WHETHER SEN CAN REBUT IT}

Sen's theory and Nussbaum's use of it have led to charges of paternalism being brought against both of them. Who are we, asks Sugden, to think that we "know better than some particular individual what is good for her'? ${ }^{10}$ What tells us that a woman who says she prefers to stay at home and care for her family, or to cover her hair when she is in mixed company, is not expressing a genuine preference? Why must we apply some universal standard to her case, especially when this universal standard appears to be molded according to the standards of the person who prescribes it? Sugden is particularly concerned with the thought that an outsider may be able to decide what an individual has or does not have reason to value, both because the concept of reason used seems to him mysterious, and because this attitude 'opens the door to restrictions on freedom'.11

\footnotetext{
9 The use of the adjective 'stunted' implies that the preferences did not develop in a natural way. I refrain, however, from describing such preferences as 'unnatural' as what is relevant is not what the preference actually is for, but how it was formed. 'Unatural preferences' might be read as meaning that there are some things that are by nature preferable and others not. This is not what I am talking about here.

${ }_{10}$ R. Sugden, 'What we desire, what we have reason to desire, whatever we might desire: Mill and Sen on the value of opportunity', Utilitas 18 (2006), pp. 33-5, 34.

11 Sugden, 'What we desire', p. 34.
} 
Worries such as Sugden's often stem from beliefs that we should take cultural differences seriously, and that paternalism is bad because it restricts an individual's freedom to choose the best life for him or herself. The cultural concern, although not obviously apparent in Sugden's argument, is nonetheless related to his claim that we should not have an 'outsider' deciding what is good for an individual. This worry is better expressed by noting that well-meaning Westerners sometimes misunderstand the culture of a developing country to the extent that by trying to help, they cause more harm than good. Martha Nussbaum, in her defense of the capabilities approach, takes this worry very seriously indeed and points out that serious mistakes have been made because of it. She suggests that any humanitarian project needs to be backed up by local knowledge in order to understand the problems faced by those we are trying to help. But, she argues,

it is quite another matter to claim that certain very general values, such as the dignity of the person, the integrity of the body, basic rights and liberties, and basic economic opportunities are not appropriate norms to be used in assessing women's lives in developing countries. ${ }^{12}$

Cultural paternalism is certainly a danger for the outsider trying to help, but one that can be avoided with careful research.

But what of the more straightforward worry that we are imposing some mysterious 'reason' on the lives of people who are quite capable of choosing for themselves what they want to do? Unlike Nussbaum, Sen does not want to specify what capabilities a human being should possess; he offers no objective standard and yet claims that we can decide some choices are bad in certain cases.

But despite the 'mystery' surrounding some of Sen's claims, it seems that he is able to reply to the paternalism objection at least as far as the phenomenon of sour grapes is concerned. ${ }^{13} \mathrm{He}$ is not claiming, he says, that people in general do not know what is good for them and that it is generally acceptable for outsiders to impose their values on the lives of others when they judge that those others do not have 'reason to value' their choices. Sen is claiming that adaptive preference is a specific problem, not a general truth about people's ability to form 'correct' valuations.

12 Nussbaum, Women and Human Development, p. 41.

13 Although it is not the case that all the phenomena described by Sen fall under the category of sour grapes. At best, sour grapes is a subcategory of adaptive preferences. Preferences can also adapt themselves to a bad situation without the subject of those preferences rejecting any actual grapes. So I can believe that my situation is fine as it is, without thinking of any particular, objectively preferable situation that would not in fact be preferable. But I find it helpful, for the sake of this discussion, to focus on instances of sour grapes. 
When the inhabitants of Kerala, who are comparatively well off, claim to suffer from poor health, and those of Bihar whose life expectancy is the shortest in India say they are happy with their health, should we simply take their word? Should we not take into account the parallel discrepancies in literacy levels and available health care? Should we not factor in the extreme conditions of poverty in which the people of Bihar have come to form the belief that they are OK? Yet, to say that the inhabitants of the poorer region are suffering from adaptive preferences is not to say that they are not, in general, capable of making up their own minds about what is good for them. It is to say that because of the extreme conditions of hardship in which they came to adopt their values, it is likely that there should be some distortion. The mysterious reason which would help them realize that this has happened need only be the reason of those who have not been subjected to such extreme circumstances.

Of course this is still paternalism in some ways. Some impartial observer, or majority, has to decide that desires formed under some circumstances are objectively better than desires formed in others. But it seems that we are still talking about an exception to the general rulethat people tend to know what is best for them - when we talk of adaptive preferences as sour grapes. Here it is helpful to think of what might be involved in the diagnosis of sour grapes. If the grapes of the fable were to be lowered, provided there was not too great a loss of face involved, no doubt the fox would recant his former rejection and eat them gladly. So similarly, one should observe relief when a gap is filled, and people are fed more, or offered the opportunity to be cleaner and healthier, work less hard, etc. If there is such relief, and no regret for the former lifestyle, then it is obvious that we were dealing with a case of sour grapes. If individuals are very reluctant to embrace their new way of life, if it takes them a long time to get used to it, then one may wonder if it really was a case of sour grapes after all. In that case we may well worry that we are interfering with the individual's liberty by insisting he eat the grapes.

Nussbaum describes one particular government project in the region of Andhra Pradesh of the construction of women's collectives. She says that, originally, both the men and the women were reluctant to take part in the project - the men because they thought it was simply an excuse for the women to work less, the women because they feared that it might provoke their husbands into behaving worse towards them, or, at best, not change anything. But once the project started, she observed that 'traditions of deference that once seemed good have quickly ceased to seem so.. ${ }^{14}$ In other words, although there was initial

${ }^{14}$ Nussbaum, Women and Human Development, p. 43. 
resistance to the grapes being lowered, once they were, they were eaten pretty quickly. There was no heavy-handed imposition of values, but rather an opportunity was perceived as lacking, and it was offered in a discreet manner and accepted. This is a good a reply to the paternalism objection, and provided we can show that sour grapes is indeed the phenomenon we are dealing with when we look at adaptive preferences, then we have little to worry about. However, I will argue that it turns out that sour grapes is only a small part of the picture and that preferences are sometimes distorted in such a way that it makes it harder to correct them without encountering the paternalism objection.

\section{WOLLSTONECRAFT ON IRRATIONAL PREFERENCES}

Sen appeals to Wollstonecraft because of her claim that even though women are oppressed they seem satisfied with their condition. This is the same basic observation which led Sen to think in terms of sour grapes. But does Wollstonecraft interpret the data in the same sense as Sen? Does she think that her contemporaries suffer from sour grapes? And if she doesn't, what implications might this have for Sen's own claims? Let us take a closer look at what she actually says.

Wollstonecraft talks of women being enslaved, rather than oppressed, and she makes it clear that they are in a sense willing victims, that they will often resist others' attempts at emancipating them, and that sometimes they will actively perpetuate the prejudices that are at the root of their condition. She echoes Rousseau's observation that 'enslaved people do nothing but boast of the peace and tranquility they enjoy in their chains'. ${ }^{15}$ This was a common enough thought at the time of the French Revolution, answering an obvious need to explain both why a large portion of society, although it did not protest, was in fact being unjustly treated, and why those who weren't enslaved had a duty to help others snap their chains. A French contemporary of Wollstonecraft, Condorcet, also writing on the rights of women refers to this same thought:

It is in the power of habit to familiarize men with the violation of their natural rights to such a degree that, among those who have lost them, nobody ever thinks of reclaiming them or supposes himself to have suffered any wrong. ${ }^{16}$

Although the phenomenon is the same, it presents a different problem when those who are unaware of the injustice committed against them

15 J.-J. Rousseau, The Basic Political Writings (Indianapolis, 1987), p. 72.

16 John Morley (trans.), 'Condorcet's Plea for the Citizenship of Women', The Subjection of Women: Contemporary Responses to John Stuart Mill, ed. Andrew Pyle (Bristol, 1995), pp. 236-43, at p. 236. Strangely, Condorcet does not relate the phenomenon he describes directly to women, he only deduces from it that men must have simply not noticed that women were oppressed. 
are women, rather than the poor. So whereas Rousseau is content to observe the phenomenon, Wollstonecraft needs to explain it for, I think, a very simple reason. Rousseau is fighting the kind of subservience that harms not only the willing slaves, but those who enjoy enough freedom to wish to change the system. This was the case in the French Revolution. The middle classes were able to help the oppressed shake off the tyranny of the oppressors because it was in their interest to do so. But this cannot happen when there is only the oppressed and the oppressor. Clearly, Rousseau's claim that we must be forced to be free will have no effect if there is no one in whose interest it is to force the slaves to be free.

Wollstonecraft is very aware of this difficulty: 'I am afraid', she says, 'that human nature is still in such a weak state that the abolition of titles, the corner stone of despotism, could only have been the work of men who had no titles to sacrifice'. ${ }^{17}$ As a result of this weakness she feels that it is unlikely that men will help women snap their chains, ${ }^{18}$ and therefore, that inequality should be combated gradually, not through a revolution, by the few individuals such as herself who see the need for it, through rational persuasion of both the oppressed and the oppressor. This may take a long time: '[W]ho can tell, how many generations may be necessary to give vigour to the virtue and talents of the freed posterity of abject slaves? ${ }^{19}$ In this, she echoes Kant, who wrote in his 'An Answer to the Question: What is Enlightenment' that:

Thus a public can only attain enlightenment slowly. Perhaps a revolution can overthrow autocratic despotism and profiteering or power-grabbing oppression, but it can never truly reform a manner of thinking; instead, new prejudices, just like the old ones they replace, will serve as a leash for the great unthinking mass. ${ }^{20}$

What Wollstonecraft thinks has to change is more than simply oppression - it is, as Kant says, a manner of thinking. What will be particularly difficult, she says, what her contemporaries will resist giving away the most, are the small comforts and pleasures that they have because they are women, because they are weak and precious and must be protected.

Confined in cages like the feathered race, they have nothing to do but to plume themselves, and stalk with mock majesty from perch to perch. It is true that they are provided with food and raiment, for which they neither toil nor

17 Mary Wollstonecraft, $A$ Vindication of the Rights of Woman, A Vindication of the Rights of Men (Oxford, 1993), p. 48.

18 Virginia Sapiro, A Vindication of Political Virtue (Chicago, 1992), p. 227.

19 Wollstonecraft Vindication of the Rights of Woman, p. 148.

20 I. Kant, 'An answer to the Question what is Enlightenment', Kant's Political Writings, ed. H. Reiss (Cambridge, 1991), p. 55. 
spin; but health, liberty and virtue are given in exchange. But where amongst mankind, has been found sufficient strength of mind to enable a being to resign these adventitious prerogatives; one who, rising with the calm dignity of reason above opinion, dared to be proud of the privileges inherent in man? And it is vain to expect it whilst hereditary power chokes the affections and nips reason in the bud. ${ }^{21}$

So one of the factors that holds women back, that makes it difficult to persuade them that they are oppressed, is their reluctance to give up those small privileges, those treats they receive in their captivity. The general thought that when a person is oppressed, she makes the most of small pleasures and become excessively attached to things that would strike them as insignificant is shared by Sen, who writes that 'in situations of long-standing deprivations, the victims ... very often make great efforts to take pleasures in small mercies'. ${ }^{22}$

If Wollstonecraft is describing something like sour grapes, then women's preference for 'burnishing their chains' and 'roaming around a gilt cage' is a false one, adapted from a realization that no matter what they do, they will never be considered equals by men, and allowed to use their reason fully in private or public. They thus chose to settle for small desires, easily gratified. But if Sen is right these are, in fact, false preferences. A woman told she can wear trousers and go to work, although she might find it difficult to give up her beauty routines and home comforts, through simple force of habit, will likely nonetheless rejoice at being offered the chance to do something she regards as more worthwhile. In other words, they should be willing to give up their small pleasures in exchange for "the sober pleasures that arise from equality'. ${ }^{23}$

But Wollstonecraft clearly does not believe this to be the case: the oppressed women fail to see the appeals of equality and liberty; they are not capable of doing so because their reason is underdeveloped or atrophied. In order for them to develop sensibility, delicacy, softness and fairness, their reason must suffer. Their sensations are 'heightened in the hot-bed of luxurious indolence at the expense of their understanding,. ${ }^{24}$ She draws her evidence from her own observations, in particular of life in an aristocratic household where she was a governess, where the mother, albeit an intelligent woman, spent more time bathing in ass's milk and flirting with visitors than in the nursery,

21 Wollstonecraft, Vindication of the Rights of Woman, p. 125.

22 Sen Inequality, p. 55.

23 Wollstonecraft, Vindication of the Rights of Woman, p. 124.

${ }^{24}$ Wollstonecraft, Vindication of the Rights of Woman, p. 140. See also pp. 132, 134, 135 . 
looking after her children or other serious, worthwhile business. ${ }^{25}$ Wollstonecraft did believe that it was a mother's duty to spend time and effort on her children, and in her letter to Talleyrand, to whom she dedicates her Vindication, she deplores the fact that without a proper education, women will not 'spend that time in their nursery ... which they choose to spend at their glass'. ${ }^{26}$ Note that Wollstonecraft does not appear to have believed, however, that it is a woman's duty to marry and become a mother. Indeed, she recommends against marriage, in some cases, and always against early marriages, on the grounds that they prevent a young woman from acquiring some knowledge and experience of the world which, together with time, is necessary for her education to mature properly. ${ }^{27}$ She also believed that more professions should be open to women so that they were not forced to marry in order to support themselves. ${ }^{28}$

Wollstonecraft also draws some evidence that women choose not to relinquish their status from what her female contemporaries say. She quotes Mrs Barbauld's comparison of a lady to a flower, because she is 'sweet, gay and delicate ... born for pleasure alone'. ${ }^{29}$ The Baroness de Stael, and her defence of Rousseau's arguments for unequality, and Mme de Genlis, and her pleadings for blind obedience to parental authority, are discussed at more length in the animadversions in Chapter Five of the Vindication. Wollstonecraft's response to their arguments is that they must be lacking in reasoning skills, if they cannot see that their views are false and insulting to their own kind: 'Indignantly', she says, 'I have heard women arguing in the same tracks as men, and adopt the sentiments that brutalize them, with all the pertinacity of ignorance. ${ }^{30}$

It seems as though adaptive preferences or sour grapes does not provide a very accurate description of the phenomenon to which Wollstonecraft is drawing our attention. Women do not, finding themselves oppressed, choose to delude themselves and settle on small pleasures in an attempt to forget their lot. But these preferences are very real, women will fight for them if someone attempts to take them

${ }^{25}$ See Claire Tomalin, The Life and Death of Marie Wollstonecraft (Littlehampton, 1974).

${ }^{26}$ Wollstonecraft, Vindication of the Rights of Woman, p. 68.

27 Mary Wollstonecraft, Thoughts on the Education of Daughters (Oxford, 1994), pp. 93-4.

${ }_{28}$ Wollstonecraft, Thoughts, p. 69 and Vindication of the Rights of Woman, p. 229. Brace, 'Not Empire but Equality', p. 435, claims that Wollstonecraft bases duties on men and women on natural division of labour, and that therefore motherhood holds an important place in virtuous womanhood. This seems less persuasive in the light of the passages I quoted in which Wollstonecraft describes what a woman might and should do.

${ }_{29}$ Wollstonecraft, Vindication of the Rights of Woman, p. 123, n. 4.

${ }^{30}$ Wollstonecraft, Vindication of the Rights of Woman, p. 176. 
away from them, and they will not value reason and virtue if they are offered to them in exchange. There is no self-deception involved, no sour grapes, as far as Wollstonecraft is concerned.

Condorcet's analysis of women's condition is perhaps closer to what Sen has in mind. Condorcet claims that women are just as reasonable as men, but that they are forced by circumstances to apply their reason to different spheres, i.e. homemaking and beauty, rather than politics and science. 'It is no more unreasonable for a woman to take pains about her personal appearance than it was for Demosthenes to take pains with his voice and gesticulation. ${ }^{31}$ Should they be granted the right to be politically active, we would see straightaway that there is nothing wrong with their reasoning capacities. In the same way, one may say that an eighteenth-century husband may not think of questioning some domestic arrangement which, if it were changed, would make him more comfortable, or happier, simply because he is not accustomed to reasoning about home matters.

But both Condorcet's analysis and my parallel example are questionable. A person may get used not to ask questions about certain topics, but then it does not follow that if she were to try, she would commit a mistake in reasoning. Reasoning skills are, after all, supposed to be transferable. What may be the case is that an eighteenth-century woman who decides, for the first time, to apply her reason to politics, will lack familiarity with concepts, ideas, vocabulary even, that makes such reasoning valuable But although she may be ignorant she need not be stupid if she has developed her reason in other spheres. For Wollstonecraft the uneducated and enslaved woman has few reasoning skills, those she needs to be pretty and cunning, but not those she needs to discuss politics intelligently.

For Sen's analysis to be right, it has to be the case that preferences that are incompatible with more advantageous choices are not real preferences. Even if habit has rendered them firmer than they would have been otherwise, the agent, confronted with the more advantageous possibility, ought to be able to think that she would be better off if she changed her way of life. Because the women Wollstonecraft talks about seem genuinely committed to their preferences and, as she would have it, incapable of adopting better ones for want of sufficient reasoning abilities, it must be the case that she is talking of something quite different from sour grapes. The question we must now turn to is why women would form such preferences in the first place, i.e. we must identify the process in order to find out whether and how it might be corrected. 


\section{PREFERENCES AS STUNTED GROWTH: THE ROLE OF EDUCATION}

Another piece of evidence that Wollstonecraft is not talking of women adapting their preferences in the face of powerlessness, is that she seems to think that their preferences are formed for them, from the very beginning, by men who are intending to make them their slaves. Men 'endeavour to enslave woman'32 and they do so by teaching them 'from their infancy that beauty is woman's scepter' as a result of which 'the mind shapes itself to the body, and, roaming around its gilt cage, only seeks to adorn its prison'. ${ }^{33}$ Small pleasures are dished out to occupy women's minds: 'she is incited by present gratification to forget her grand destination'. ${ }^{34}$ This education ensures the stunted growth of women's minds, and enslaves them: 'Thus degraded, her reason, her misty reason! is employed rather to burnish than to snap her chains. ${ }^{35}$

Mill also describes women's condition as the result of stunted growth:

in the case of women a hot-house and stove cultivation has always been carried on some of the capabilities of their nature, for the benefit of their masters. Then because certain products of the general vital force sprout luxuriantly and reach a great development in this heated atmosphere and under this active nurture and watering, while other shoots from the same root, which are left outside, in the wintry air, with ice purposefully heaped all around them, have a stunted growth, and some are burnt off with fire and disappear ... ${ }^{36}$

Mill and Wollstonecraft share the suggestion that women's capacity to flourish, their capabilities, are manipulated from the very beginning. They even use the same gardening analogy which they use to express that view. ${ }^{37}$ This is a common enough analogy, and Wollstonecraft's contemporaries would have been used to hearing of the cultivation of the woman's mind, either through comparisons of women to pretty flowers (Barbault, as we saw, but also Burke in his Philosophical Inquiry), to decadent and showy flowers (Pope's claim that women, like tulips, are 'fine by defect' and Swift's famous line 'such gaudy tulips raised from dung'), or through Rousseau's advice that women should refrain from too much cultivation, and be as close as possible to nature. $^{38}$

32 Wollstonecraft, Vindication of the Rights of Woman, p. 148.

33 Wollstonecraft, Vindication of the Rights of Woman, p. 112.

${ }^{34}$ Wollstonecraft, Vindication of the Rights of Woman, p. 133.

35 Wollstonecraft, Vindication of the Rights of Woman, p. 176.

36 J. S. Mill, The Subjection of Women in On Liberty and Other Writings (Cambridge, 1989), p. 139.

37 The 'hot-bed' Wollstonecraft refers to (Vindication of the Rights of Woman, p. 140) was the eighteenth-century equivalent of the hot-house, a pit filled with horse manure and covered with glass.

${ }^{38}$ For an insightful discussion of these gardening analogies in the eighteenth century, see Sam George, 'The cultivation of the female mind: enlightened growth, luxuriant 
As far as both Mill and Wollstonecraft are concerned, the growth of women's rational and moral abilities is stunted, and the growth of their feminine attributes, such as they are perceived in the two philosophers' respective centuries, are unnaturally enhanced, through 'hot-house' cultivation. But it seems that Wollstonecraft and Mill nonetheless differ in their analysis of why this systematic distortion of women's capabilities occurs in the first place. Mill seems to believe that there is an almost conscious manipulation of women's capabilities by men. Men want slaves, if possible willing slaves who will serve without resentment and without any prompt from their masters.

All men, except perhaps the most brutish, desire to have, in the woman most nearly connected with them, not a forced slave but a willing one [. . . So men have] put everything in practice to enslave their minds. ${ }^{39}$

Frances Power Cobbe, in her review of the Subjection of Women, felt that Mill did not emphasize this aspect of women's oppression sufficiently. ${ }^{40}$ She talks of the unnatural aspect of 'the characters and abilities of creatures manipulated as women are ${ }^{41}$ and describes the process of the manipulation as follows. 'She may freely grow, and even swell to abnormal proportions in the region of the heart; but the head has but a small chance of expansion and the whole base is weak and rickety to the extreme. ${ }^{42}$

The idea that men deliberately manipulate women as they would an exotic flower, so as to maximize the pleasing effects whilst minimizing the inconvenience, is somewhat dubious. One is reminded of the 1972 Bryan Forbes film Stepford Wives in which the men of a small town clubbed together to robotize their wives, thereby ensuring that they conformed to their ideal of what women should be like, and become, literally, willing slaves. Jon Elster, in his work on sour grapes, pointed out, reasonably enough, that such systematic manipulation is unlikely to be the result of conscious conspiracy. For such a scenario to be in place men would first have to be aware that women are capable of wanting the same kinds things out of life as they do, then realize that they could effect certain changes to women's desires that would be to men's, but not to women's, advantage, and then cooperate to effect those changes. It does seem unlikely that men, as a group, would go through such a

decay, and botanical analogy in eighteenth century texts', History of European Ideas 31 (2005), pp. 209-23.

39 Mill, Subjection of Women, p. 132.

${ }^{40}$ Frances Power Cobbe, 'The Subjection of Women', in Pyle, The Subjection of Women, pp. $54-74$.

41 Cobbe, 'The Subjection of Women', p. 60.

${ }^{42}$ Cobbe, 'The Subjection of Women', p. 61. 
mental process. It would require an unlikely degree of cooperation and of sheer unpleasantness on the part of men.

Wollstonecraft, for all her unflinching rebuttals of men's preconceptions about women, and their treatment of their womenfolk, does not share Mill's and Cobbe's conspiracy theory. Her assessment of how a mind is formed is not compatible with such a view, as she believes that education and habituation can only encourage the birth of the mind. But a mind can only be created through reflection on what it has acquired:

It may be observed, that I recommend the mind's being put into a proper train, and then left to itself. Fixed rules cannot be given, it must depend on the nature and strength of the understanding; and those who observe it can tell what kind of cultivation will improve it. The mind is not, cannot be created by the teacher, though it may be cultivated and its real powers found out. ${ }^{43}$

What Wollstonecraft believes is that at least as significant as the habituation to frivolity in the shaping of her contemporaries, consciousness is the lack of formal education which she discusses in the Vindication but also in her very first book, On the Education of Daughters. Whereas boys are taught formally from an early age, women 'receive only a disorderly kind of education'. In particular, women are not trained to apply themselves to detail, or 'with exactness', and develop no sense of method. What they acquire instead is 'a negligent kind of guesswork' which leads to an inability to 'generalize matters of fact'. ${ }^{44}$ Wollstonecraft emphasizes that early education is the only remedy to this defect as 'a child very soon contracts a benumbing indolence of mind, which, he has seldom sufficient vigour afterwards to shake off. ${ }^{45}$

Other factors in women's apparent inability to mature intellectually are a tendency to leave little girls in the care of ignorant nurses who will 'humour all her little caprices' ${ }^{46}$ and encourage them to become gossips. ${ }^{47}$ Also relevant is the fact that girls and young women are not engaged in any serious activity which would 'silence their feelings' and

${ }^{43}$ Wollstonecraft, Thoughts, p. 54. Although Wollstonecraft would agree with Elster's rejection of the view that sour grapes can be the result of indoctrination, she would do so for different reasons. Elster (Sour Grapes, p. 117) thinks that indoctrination is only successful when the indoctrinator sincerely believes what he is preaching. But Wollstonecraft's claim is more radical as she seems to believe that the mind cannot be manipulated but ultimately must create itself.

${ }_{44}$ Wollstonecraft, Vindication of the Rights of Woman, p. 88.

45 Wollstonecraft, Vindication of the Rights of Woman, p. 241.

46 Wollstonecraft, Thoughts, p. 5.

47 Wollstonecraft, Vindication of the Rights of Woman, p. 109. 
allow their minds to become stronger. ${ }^{48}$ Instead, Wollstonecraft says, 'trifling employments have rendered woman a trifler'. ${ }^{49}$

Last but not least, Wollstonecraft blames early marriage, because it prevents women's mind from having the proper time to digest the education it has received and mature.$^{50}$ Early marriage also takes away the advantages men derive from 'being obliged to struggle with the world', such as seeing human nature 'as it is' rather than living purely in their imaginations as women who leave their parents' home only to become wives and mothers tend to. ${ }^{51}$

The cumulative effect of this neglect of women's education is likely, eventually, to be very similar to Mill's conspiracy theory: women fail to develop strong reasoning skills, virtuous character, proper concern for others and wider interests. They are concerned with little other than dress and gossip. Note, of course that Wollstonecraft does not believe that the only thing that is holding her contemporaries back is vanity! She has much to say about the lot of poorer women coping single-handedly with hordes of dependents while their husbands do little to help them, or women forced into prostitution because there is a market for it and no other profession open to them which would enable them to support themselves when no one else can. But Wollstonecraft does not claim, and she is right not to, that such women would not welcome change were it offered to them! Her target, and the object of the arguments I have just described, is the class of women who are well enough off to be supported in idleness by their male relatives.

\section{WHY WE NEED TO APPEAL TO UNIVERSAL VALUES IN ORDER TO DEAL WITH IRRATIONAL PREFERENCES}

Sen rebuts Sugden's charges of paternalism by saying that the theory of adaptive preferences is not a 'general problem' but a 'specific problem of some importance that has to be addressed'. ${ }^{52}$ Of course if we're talking about sour grapes, the problem is specific: it is based on each individual's ability to face up to dire situations, and to deceive herself. At the same time, if a lot of individuals do that, then it is a specific problem on a large scale. But if Wollstonecraft is right, then what we are dealing with is a systematic, rather than a specific, problem. According to her, women grow up preferring pretty clothes to independence, so at no point do they take the step of lying to themselves that this is what they prefer. Sugden is right and their life style is, in some important

\footnotetext{
48 Wollstonecraft, Vindication of the Rights of Woman, p. 146.

49 Wollstonecraft, Vindication of the Rights of Woman, p. 148.

50 Wollstonecraft, Thoughts, pp. 93-4.

51 Wollstonecraft, Thoughts, p. 100.

52 Sen, 'Reason', p. 88.
} 
sense, their own choice. By criticizing it, we are indeed questioning their ability to think for themselves and work out what is good for them. But Wollstonecraft does believe both that women do choose their life for themselves, and that they are not truly capable of making the right choice:

[T] hey have, to maintain their power, resigned the natural rights, which the exercise of reason might have procured them, and chosen rather to be short-lived queens than labour to obtain the sober pleasure that arise from equality.... And it is in vain to expect [a realization that they are deluded] whilst hereditary power chokes affections and nips reason in the bud. ${ }^{53}$

Sen would probably maintain that in the case of world poverty, what we are dealing with is sour grapes rather than stunted growth, as much poverty is a matter of bad luck - political or natural disasters - which require an adjustment on the part of the individual, but not a mass breeding of people accepting their fates. But even Sen recognizes that where there is poverty or oppression, women tend to be both worse off and more accepting. Here we may question whether Sen is not in fact dealing with two different phenomena, that of adaptive preferences, and that of systematically stunted preferences. If that is right, then he cannot simply dismiss the paternalism charges by saying that he is talking of a specific problem on a large scale.

Nussbaum, who is less shy of universalism, takes the charges head on. Because some cultures systematically deny women the right to proper human development, we need to appeal to universal values in order to defend these rights against cultural prejudice. Like Sen, Nussbaum claims that we do not need to defend actual functioning, i.e. we do not need to ensure that people everywhere live similar lives, but we need to defend capabilities for functionings. Every single human being should be able, should she wish, to function in a way that is similar enough to other human beings.

The requirement for a common core of capabilities need not represent any threat to diversity. Even if one has a certain capability, one may choose not to function in that way. On the other hand, it matters that one at least has the capabilities we deem human, and that one can choose whether or not to exercise them. Compare, for example, a nun who has taken a vow of silence with a child who has not been taught to speak. Neither of these makes use of the function of speech, but only the nun has the capability to speak. But to claim that she has a right not to speak certainly does not imply that anyone has a right to stop a child from learning to speak.

${ }^{53}$ Wollstonecraft, Vindication of the Rights of Woman, p. 124. 
Similarly, although a woman may choose to live a life that is very different from that of the men in her family, to differentiate herself by her sex and seek bodily comforts in exchange for the free exercise of her reason, in order to make that choice, she needs rational abilities that are sufficiently developed in the first place. If she is to decide that her place in life should differ from those of men, she needs to start off from the same place, which means that she needs to have received an identical upbringing.

When Sen pays his dues to Wollstonecraft, he shows us that his nonuniversalist position is a precarious one. Wollstonecraft is very clear that the willing oppression of women is caused by a systematic stunting of the growth of their rational capacities, and an excessive nurturing of their love for comfort and small pleasures. Women do not suffer from sour grapes, they are just brought up that way. It is likely that amongst the injustices Sen describes, some of them, mainly related to women, still belong to the category Wollstonecraft describes. If that is so, then we are forced to prefer Nussbaum's more universalist solution to the problem over Sen's. ${ }^{54}$

sandrineberges@gmail.com

54 Thanks to Anca Gheaus, Lena Halldenius, Lars Vinx, Simon Wigley, Bill Wringe for their feedback, and to the audiences at the 2009 Philosophy in Assos conference and at the SWIP session of the 2009 Joint Session of the Aristotelian Society and the Mind Association conference. 